Anna Ambrochowicz-Gajownik

Biblioteka Uniwersytecka w Olsztynie annaambrochowicz@interia.pl

\title{
Polsko-francuskie stosunki gospodarcze w okresie międzywojennym: nowe postulaty badawcze
}

Słowa kluczowe: Druga Rzeczpospolita, Trzecia Republika, służba konsularna, dyplomacja, ekonomia

Keywords: The Second Republic, the Third Republic, consular service, diplomacy, economy

Polish-French economic relations in the interwar period: new research postulates Summary: Economic relations of the Second Polish Republic with the French Third Republic were derived directly from political relations between these two states. Because of its position in the international arena, France set the terms of trade exchange which the Polish side was supposed to comply with. It stemmed from the economic hardship Poland was experiencing at that specific time. One possible solution was acquiring considerable French funds. The flow of goods in both directions took place, primarily, by sea, and control over the import of French products was exercised by the Polish consulates in France. Despite the increasing circulation of goods, facilitated by the newly-signed treaties and economic agreements, the overall trade balance was negative. The great economic crisis in the thirties intensified in France the use of quota policy elements, which negatively affected the bilateral relations. In these circumstances, Poland began to seek other methods of selling its domestic products, especially, to distant continents - Africa, the Middle and Far East.

Opisanie stosunków gospodarczych między Drugą Rzecząpospolitą a Trzecią Republiką Francuską to dla badaczy nie lada wyzwanie. Wciąż brakuje syntezy owych relacji, która stanowiłaby dopełnienie omawianych w literaturze naukowej stosunków politycznych, wojsko- 
wych, dyplomatyczno-konsularnych ${ }^{1}$. Niemniej, w fundamentalnych pracach Zbigniewa Landaua i Jerzego Tomaszewskiego, traktujących o polskiej gospodarce, przewija się problematyka wzajemnych kontaktów handlowych obu państw, stanowiąca pole wyjścia do podjęcia przyszłych badań w tym zakresie ${ }^{2}$. Niniejsza publikacja jest próbą

${ }^{1}$ Bułhak H., Polska - Francja z dziejów sojuszu 1922-1939: cz. I (1922-1932), Warszawa 1993; idem, Polska - Francja z dziejów sojuszu 1933-1936, Warszawa 2000; Ciałowicz J., Polsko-francuski sojusz wojskowy 1921-1939, Warszawa 1970; Dessberg F., Le triangle impossible. Les relations franco-soviétiques et le facteur polonais dans les questions de sécurité en Europe (1924-1935), Bruxelles-BernBerlin-Frankfurt am Main-New York-Oxford-Wien 2009; Davion I., Mon voisin, cet ennemi. La politique de sécurité française face aux relations polono--tchécoslovaques entre 1919 et 1939, Bruxelles-Bern-Berlin-Frankfurt am Main-New York-OxfordWien 2009; Pasztor M., Polska w oczach francuskich kół rzadowych w latach 19241939, Warszawa 1999; Polska - Francja. Dziesięć wieków związów politycznych, kulturalnych i gospodarczych, pod red. A. Tomczaka, Warszawa 1983; Rollet H., La Pologne au XXe siècle, Paris 1984; Soutou G., L'alliance franco-polonaise (19251933) ou comment s'en débarrasser?, „Revue d'Histoire diplomatique”, 1981, nr 2-4, s. 295-348; Soutou G., La politique economique de la France en Pologne, „Revue Historique” 1974, nr 251, s. 88-89; Schramm T., Francuskie misje wojskowe w państwach Europy Środkowej 1919-1938, Poznań 1987; Skóra W., Stużba konsularna Drugiej Rzeczypospolitej. Organizacja, kadry i działalność, Toruń 2006; Wandycz P., Aleksander Skrzyński minister spraw zagranicznych II Rzeczypospolitej, Warszawa 2006; idem, $Z$ dziejów dyplomacji, Londyn 1988; idem, France and her Eastern Allies 1919-1925. French-Czechoslovak-Polish Relations from the Paris Peace Conference to Locarno, Minneapolis 1962; idem, Z Pitsudskim i Sikorskim. August Zaleski minister spraw zagranicznych w latach 1926-1932 i 1939-1941, Warszawa 1999; idem, The Twilight of French Eastern Alliances 1926-1936: French-Czechoslovak-Polish Relations from Locarno to the Remilitarization of the Rhineland, Princeton 1988; Wołos M., Alfred Chłapowski (1874-1940). Biografia ambasadora Polski we Francji, Torun 2001.

${ }^{2}$ Landau Z., Tomaszewski J., Kapitaty obce w Polsce 1918-1939: Materiaty i dokumenty, Warszawa 1964; idem, Gospodarka Polski międzywojennej 19181939. T. I. W dobie inflacji 1918-1923, Warszawa 1967; idem, Gospodarka Polski międzywojennej 1918-1939, T. III. Wielki kryzys 1930-1935, Warszawa 1982; idem, Gospodarka Polski międzywojennej 1918-1939, T. IV. Lata interwencjonizmu państwowego 1936-1939, Warszawa 1989; idem Od Grabskiego do Piłsudskiego. Okres kryzysu poinflacyjnego i ożywienia koniunktury 1924-1929, Warszawa 1971; idem, Zarys historii gospodarczej Polski 1918-1939, Warszawa 1999; idem, Plan stabilizacyjny 1927-1930: Geneza, założenia, wyniki, Warszawa 1963, idem, Polska w Europie i świecie 1918-1939, Warszawa 2005. 
ukazania wymiany handlowej z perspektywy konsulatu polskiego w Marsylii. Port marsylski miał szczególne znaczenie dla polskiego eksportu, zważywszy na jego istotną rolę wśród szlaków komunikacyjnych łączących Francję z Afryką, Bliskim i Dalekim Wschodem. Główne ośrodki miejskie nad którymi Trzecia Republika sprawowała mandat i protektorat, odgrywały istotną rolę w stosunkach gospodarczych między Polską a Francją. Problematykę tę poruszył w swojej monografii Przemysław M. Żukowski ${ }^{3}$. Temat wciąż zasługuje na dalsze pogłębione badania, jak w przypadku choćby wymiany handlowej w portach francuskich, do których dostarczano polskie towary, co wiązało się z problemem transportu tychże drogą morską. Stan badań w tej kwestii jest nader skromny ${ }^{4}$.

Sytuacja ekonomiczna Drugiej Rzeczpospolitej i Trzeciej Republiki, choć niewspółmierna porównawczo, w obu przypadkach nie była dobra. Rzeczpospolita odradzała się na nowo, zaś Francja podnosiła się ze zniszczeń wojennych, odbudowując swoją gospodar$\mathrm{kę}^{5}$. Oba kraje potrzebowały wsparcia finansowego - Francja liczyła na spłatę reparacji ze strony Niemiec, a Polska na pomoc obcego kapitału w postaci pożyczek. Niestabilna sytuacja Polski na arenie międzynarodowej w początkach tworzenia się bytu państwowego niejako pomagała mocarstwom zachodnim wstrzymać się z podjęciem decyzji o wsparciu finansowym. Wielkie mocarstwa uważały, że Polska stanowi państwo ,sezonowe”, ze względu na nieuregulowane sprawy granic. Nad Wisłą oczekiwano poparcia mocarstw zachodnich w sprawie odzyskania Górnego Śląska. Uzyskano je jedynie nad

\footnotetext{
${ }^{3}$ Żukowski P.M., Na przełomie wojny i pokoju. Francja w oczach polskiej opinii publicznej od wiosny 1938 roku do lata 1940 roku, Kraków 2012.

${ }^{4}$ Miciński S., Kolicki S., Pod polska bandera, Gdynia 1962.

${ }^{5}$ Vinen R., France 1934-1970, New York 1996, s. 1-2; Baszkiewicz J., Historia Francji, Wrocław-Warszawa-Kraków 2008, s. 539-540; Bettelheim Ch., Ekonomika Francji 1919-1997, Paris 1998, s. 31-51; Ambrochowicz-Gajownik A., Opieka nad emigracja polska we Francji w działalności Konsulatu RP w Marsylii w latach 30. XX wieku, „,Echa Przeszłości” 2015, nr XVI, s. 175-177.
} 
Sekwaną. Francji zależało na osłabieniu Niemiec ${ }^{6}$. Ponadto Trzeciej Republice zależało na ulokowaniu swojego kapitału na tym terenie, o czym świadczył układ podpisany 17 stycznia 1920 r. ${ }^{7}$, uzupełniony 20 lutego $1921 \mathrm{r}$. Kwestie te zostały dokładnie opisane przez Z. Landaua. Układ umożliwił udzielenie Polsce trzech pożyczek na stworzenie przedsiębiorstwa „Skarboferm”, wykupienie niemieckich przedsiębiorstw, założenie banku francusko-polskiego na Górnym Śląsku . Polska niewiele skorzystała na tym układzie, idąc na dalekie ustępstwa. Dlatego też, nie bez powodu, wiceminister Władysław Skrzyński powiedział, że „[Francja - A. A.-G.], o ile jest szlachetnq w polityce, o tyle jest drażliwa przy wszelkich ukladach finansowych". Nie sposób nie zgodzić się z drugą częścią zdania, co pokazały dalsze lata współpracy gospodarczej, zaś stwierdzenie o „szlachetności Francji w polityce" było zbyt dalekim uproszczeniem.

W tym samym czasie strona francuska wysunęla propozycję zawarcia umowy naftowej, korzystnej tylko dla Francuzów. Z tą kwestią związana była również sprzedaż cukru do Francji. Na poczet sprzedaży cukru konsorcjum banków francusko-polskich miało udzielić kredytu, tytułem awansu, w wysokości 100 mln franków. Minister Grabski zaproponował stronie francuskiej, że w latach 1920-1921 Polska wyśle do Francji od 30 do 40 tys. ton cukru. Grabski wyszedł z inicjatywą, że z tej sumy 30 mln odda od razu, zaś resztę miał przeznaczyć na cele wojskowe. Jednak propozycja polska nie spotkała się z pozytywną reakcją ze strony francuskich partnerów, którzy

\footnotetext{
${ }^{6}$ Landau Z., Gospodarcze i polityczne tło kredytów francuskich dla Polski w okresie 1921-1923, „Sprawy Międzynarodowe” 1959, R.12, nr 7/8, s. 39-57.

${ }^{7}$ Umowa ta nie weszła w życie, gdyż została uzupełniona rok później. Rząd francuski zgodził się pożyczyć Polsce od pół miliarda do 1 miliarda marek niemieckich na wykup przedsiębiorstw niemieckich w Polsce. Oczywiście wykupienie ich miało przejść w ręce spółki francusko-polskiej. Ibidem, s. 43-44; Wandycz P., France and her Eastern Allies..., s. 219.

${ }^{8}$ Landau Z., op. cit., s. 45-46.

${ }^{9}$ Landau Z., Tomaszewski J., Kapitaty..., s. 61.
} 
wykorzystując wpływy na Quai d'Orsay, doprowadzili do zerwania negocjacji. Polska dostarczyła jedynie 15 tys. ton cukru Francji ${ }^{10}$.

Powyższe umowy były początkiem kształtowania się stosunków gospodarczych. Wówczas ważnym przedsięwzięciem w rozwijaniu wymiany handlowej było powstanie Polsko-Francuskiej Izby Handlowej z siedzibami w Paryżu i Warszawie ${ }^{11}$. Patrząc przez pryzmat własnej ekonomiki (importu/eksportu), nie ulega wątpliwości, że Francja domagała się pozycji bardziej uprzywilejowanej niż jej kontrahent. Dotychczasowe kontakty ze Wschodem (współpraca gospodarcza z carską Rosją), skłaniały stronę francuską do przekonania, iż także Polska będzie stanowić dogodny rynek dla luksusowych towarów. W celu uzyskania odpowiednich warunków w wymianie towarowej, wykorzystywała słabszą pozycję negocjacyjną strony przeciwnej, która w wymiarze spraw politycznych i wojskowych, niejako przystawała na rolę klienta. Druga Rzeczpospolita potrzebowała wsparcia Francji na konferencji pokojowej w Paryżu oraz w sprawach wojskowych. W tym ostatnim przypadku, współpraca została zapoczątkowana 4 czerwca 1917 r., kiedy to prezydent Raymond Poincaré podpisał dekret umożliwiający powołanie do życia Armii Polskiej, podlegającej dowództwu francuskiemu. Jej organizacją kierowała Francusko-Polska Misja Wojskowa, której na czele stał generał Louis Archinard. Od 4 października 1918 r., dowódcą Armii Polskiej został Józef Haller ${ }^{12}$.

${ }^{10}$ Ibidem, s. 77-78; Soutou G., La politique economique..., s. 88-89.

${ }^{11}$ Durka J., „Polska - Francja” Organ prasowy Izby Handlowej Polsko - Francuskiej wobec wspótpracy obu państw w latach 1937-1938, [w:] Spogladając na Marianne. O Francji i Francuzach w pierwszej połowie XX wieku z polskiej perspektywy, pod red. M. Białokura, A. Karbowiaka, Opole-Bielsko-Biała 2014, s. 112-126. Izba w Paryżu została utworzona 31 marca 1920 r. Rok później ustalono, że Izba działająca w Paryżu i Warszawie miała tworzyć katalog ofert towarów. Procès-verbaux des séances du Comité. Séance du 1.04.1920. „Chambre du Commerce d' Exportation" nr 2 z 04-05.1920, s. 14; Procès - verbaux des séances $d u$ Comité. Séance du 2.06.1921. „Chambre du Commerce d' Exportation” nr 6 z 06.1921 , s. 82.

${ }^{12}$ Schramm T., op. cit., s. 14; Wandycz P., Polska..., Paryż 1986, s. 49-70. 
Rolą strony francuskiej było umożliwienie przerzucenia armii Hallera do Polski w 1919 r., a także wyszkolenie polskich żołnierzy. Francja na ten cel przeznaczyła środki finansowe, które traktowano jako część zaciągniętego kredytu ${ }^{13}$. Stan polskiej armii pozostawiał wiele do życzenia. Polska zmuszona była pozyskać kolejny kredyt na dostawy broni, umundurowania i transportów wojskowych. Kwestią tą zajęły się reprezentujące interesy Wojska Polskiego: Polska Misja Wojskowa (gen. por. Tadeusz Jordan Rozwadowski) oraz Polska Wojskowa Misja Zakupów (gen. ppor. Jan Romer) ${ }^{14}$. Podsumowując, Druga RP otrzymywała wsparcie finansowe, ale jednocześnie musiała spłacać dług, między innymi w postaci wspomnianego wcześniej cukru do Francji.

Niestabilne położenie Polski na arenie międzynarodowej, wymagało uzyskania wsparcia politycznego, militarnego i finansowego od Francji. W wyniku przeprowadzonych rozmów zawarto w Paryżu w 1921 r. układ polityczny (19.02) oraz konwencję wojskową (21.02). W aneksie do konwencji wojskowej Francja przyznawała Polsce kredyt w wysokości 400 mln franków jako pomoc w rozbudowie i dozbrojeniu wojska. Jednakże zarówno konwencja wojskowa, jak i układ polityczny wchodziły w życie z chwilą zawarcia umów gospodarczych ${ }^{15}$. Trzecia Republika chciała w ten sposób uzyskać jak największą kontrolę własnego kapitału w Polsce. Ówczesne położenie militarne i polityczne państwa nad Wisłą wymuszało podjęcie, w jak najkrótszym czasie, decyzji o finalizacji umów sojuszniczych z Fran-

${ }^{13}$ Ibidem, s. 16-17; Wandycz P., Z dziejów..., s. 59; Landau Z., Tomaszewski J., Kapitaty..., s. 77; Mazur W., Pod wiatr: Francja i lotnictwo wojskowe II Rzeczypospolitej 1921-1938, Kraków 2015, s. 13-14.

${ }^{14}$ Majzner R., Attachaty wojskowe Drugiej Rzeczypospolitej 1919-1945. Strukturalno-organizacyjne aspekty funkcjonowania, wyd. 2, Częstochowa 2014, s. 158. W 1921 roku, w myśl rozkazów gen. Kazimierza Sosnkowskiego - ministra spraw wojskowych, obie instytucje scalono w Polską Misję Wojskową składającą się z Biura Wojskowego (personel attachatu) i Biura Zakupów (personel Polskiej Wojskowej Misji Zakupów), zob. Ibidem, s. 167-168.

${ }^{15}$ Bułhak H., Polska-Francja...,s. 16-17. 
cją. Jednocześnie pojawiły się trudności ze strony rządu francuskiego, wywołane ówczesną sytuacją międzynarodową.

Do lutego 1922 r. francuskie koła rządowe z Aristide'em Briandem na czele przechodziły okres próby zbliżenia się do Wielkiej Brytanii. Stanowiło to zagrożenie dla sojuszu polsko-francuskiego. Miękka polityka Brianda oznaczała odprężenie w stosunkach z Niemcami, na co liczyła Wielka Brytania. Dla polskiej dyplomacji był to okres wzmożonej aktywności, zwłaszcza że mocarstwa zachodnie zaplanowały wiosną 1922 r. konferencję w Genui z udziałem Niemiec i Rosji. Poczynania Brianda nie były dobrze odbierane nad Sekwaną, dlatego też ster rządów od stycznia 1922 r. przejął Raymond Poincaré. Dla strony polskiej był to zwrot akcji w dotychczasowych rozgrywkach politycznych. Poincaré uprawiał rygorystyczną politykę wobec Niemiec. Polska dyplomacja wykorzystała ową zmianę i podjęła rozmowy zmierzające do podpisania układu gospodarczego. Nad Wisłą zdawano sobie sprawę, że niepodległy byt uzależniony jest od Francji. Dostrzegano również, że Francja traktuje Polskę jako bufor między Niemcami a Rosją. Jednak w ówczesnej sytuacji uważano za słuszne pójście na ustępstwa.

Do finalizacji wcześniejszych układów doszło 6 lutego 1922 r., kiedy to Polska i Francja podpisały traktat handlowy, nawiązując tym samym oficjalne stosunki gospodarcze. Zawarciu tego układu towarzyszyło podpisanie szeregu umów gospodarczych ${ }^{16}$. Strona francuska otrzymała większe korzyści w wyniku przyznania jej klauzuli największego uprzywilejowania. Obejmowała ona produkty wytworzone we Francji, jej koloniach i protektoratach. Obie strony zagwarantowały ochronę nazw pochodzenia produktów, ustaliły zniżki celne dla wyrobów uwzględnionych w specjalnej taryfie. Francja uzyskała do

\footnotetext{
${ }^{16}$ Archives du ministère des Affaires étrangères [dalej: AMAE], Pologne, vol. 249, Konwencja handlowa polsko-francuska z 1922 roku, k. 3-11; Landau Z., Tomaszewski J., Gospodarka Polski międzywojennej 1918-1939. T. I..., s. 336; Wołos M., Alfred Chtapowski..., s. 139.
} 
$50 \%$ ulgi stawek celnych dla towarów luksusowych: win, przypraw, tytoniu, wódek, serów, wyrobów skórzanych, korkowych, drewnianych, porcelanowych, motoryzacyjnych, kauczuku, mydła, kosmetyków, oraz konfekcji. W zamian Polska mogła wysyłać, także według najniższych stawek taryfy celnej: produkty rolne, mięso, warzywa, nabiał, naczynia kuchenne, drewno ${ }^{17}$. Ponadto strona polska, nie mając podpisanych umów handlowych z koloniami francuskimi, nie mogła korzystać z ulg celnych przy sprowadzaniu towarów z tych terenów. Zatem produkty kolonialne, znajdujące się na specjalnej liście „D”,jak kakao, kawa, herbata, przyprawy korzenne, bawełna, wełna, jedwabie, kauczuk miały najwyższy stopień uprzywilejowania ${ }^{18}$. Wraz z umową handlową została podpisana jeszcze umowa naftowa ${ }^{19}$.

Charakter relacji dwustronnych trafnie podsumował Piotr Wandycz twierdząc, że stosunki gospodarcze od samego początku nacechowane były nieufnością z obu stron, jednak w praktyce większe korzyści odnosiła w tej materii Francja. Polska, potrzebując kapitału francuskiego, by wypełnić lukę, jaka powstała w wyniku wycofania się kapitału niemieckiego, zmuszona była jednocześnie zapłacić za sojusz polityczno-wojskowy ustępstwami gospodarczymi ${ }^{20}$. W dniu 27 czerwca 1922 r. doszło do ratyfikacji traktatu. Polska od tego momentu oczekiwała od Francji realizacji postanowień konwencji wojskowej w kontekście realizacji przyznanego kredytu.

Ratyfikowanie umowy handlowej nie przyczyniło się do uzyskania $400 \mathrm{mln}$ pożyczki na cele wojskowe. Rozmowy w tej sprawie przeciągały się ze względu na stanowisko francuskiego Ministerstwa Finansów, które wstrzymywało realizację kredytu.

\footnotetext{
${ }^{17}$ Landau Z., Tomaszewski J., Gospodarka Polski międzywojennej 1918-1939, T. I..., s. 336-337.

${ }^{18}$ Centralne Archiwum Wojskowe [dalej: CAW], Oddział II Sztabu Generalnego [dalej: O. II SG] sygn. I.303.4.7447, Raport ekonomiczny za rok 1928. Stosunki handlowe polsko-francuskie, Lille 1928 r., s. 7.

${ }^{19}$ Landau Z., Tomaszewski J., Kapitały..., s. 83-85.

${ }^{20}$ Wandycz P., Z dziejów..., s. 72-73.
} 
Nad Sekwaną i Tamizą przygotowywano się wtedy do konferencji genueńskiej. Nie przyniosła ona oczekiwanych skutków, jednak nastąpił zwrot w stosunkach niemiecko-rosyjskich, których delegacje podpisały układ w Rapallo w kwietniu 1922 r. Do jesieni 1923 r. zarówno Francja, jak i Wielka Brytania, zajmowały zdecydowanie nieprzychylne stanowisko wobec problemu przyznania pożyczek Polsce. Sytuacja wewnętrzna Polski - częste zmiany rządów, zła koniunktura gospodarcza - utrudniały prowadzenie inwestycji zagranicznym firmom. Francja w tym czasie również zmagała się z problemami - okupacja Zagłębia Ruhry z początkiem 1923 r., następnie kryzys gospodarczy ${ }^{21}$. Anglia zaś, niezadowolona z posunięć Francji wobec Niemiec, nie chciała wzmacniać sojusznika, tym bardziej, że oba mocarstwa rywalizowały ze sobą na kontynencie europejskim ${ }^{22}$. Polska dyplomacja zabiegała o pozyskanie Wielkiej Brytanii przede wszystkim w dziedzinie gospodarczej $^{23}$. Zabiegi te dostrzeżono na Quai d'Orsay. Z dniem 1 sierpnia nawiązano współpracę morską. W Polsce rozpoczęła swą działalność Francuska Misja Morska na czele z komandorem Jolivetem. Natomiast 26 listopada stronie polskiej udało się podpisać polsko-brytyjski traktat handlowo-nawigacyjny, który regulował stosunki gospodarcze ${ }^{24}$.

Koniec 1923 roku przyniósł załamanie gospodarcze w Polsce $^{25}$. Nowy rząd Władysława Grabskiego zmagał się z niestabilną sytuacją wewnętrzną. Działania dyplomacji polskiej zmierzały do lawirowania między Francją a Wielką Brytanią o pozyskanie środ-

\footnotetext{
${ }^{21}$ Batowski H., Między..., s. 108-109.

${ }^{22}$ Landau Z., Tomaszewski J., Druga Rzeczpospolita..., s. 341-351.

${ }^{23}$ Wandycz P., Aleksander Skrzyński..., s. 92.

${ }^{24}$ Kania K., Edward Bernard Raczyński 1891-1993 dyplomata i polityk, Warszawa 2014 r., s. 38.

25 Fronczek-Kwarta A., Polityka finansowa i gospodarcza rzadu Władysława Grabskiego w okresie reformy walutowo-skarbowej (1923-1925), Poznań 2014, s. 19.
} 
ków finansowych. Dużym sukcesem było definitywne uregulowanie kwestii 400 mln kredytu na cele wojskowe ${ }^{26}$. Ponadto 4 listopada obie strony podpisały umowę w sprawie budowy portu w Gdyni. Fakt ten miał wymierne korzyści w ramach wymiany handlowej. Niemniej jednak, rozwój sytuacji politycznej w Europie w 1924 r. poważnie komplikował sytuację Polski. Mocarstwa zachodnie były żywo zainteresowane uznaniem Związku Radzieckiego de iure. W grę wchodziły głównie względy ekonomiczne. Z początkiem stycznia zmieniła się siła polityczna w Wielkiej Brytanii, do władzy doszedł James Ramsey MacDonald. Niemcy, Wielka Brytania i Włochy uznały Związek Radziecki, zaś Francja miała niezdecydowaną postawę, dlatego mediacji w procesie nawiązania dwustronnych stosunków podjął się Edvard Beneš ${ }^{27}$. Sytuacja znacznie się zmieniła, gdy wybory w maju wygrał Kartel Lewicy. Od tego momentu kwestia uznania ZSRR przez Francję była przesądzona. Równolegle można było dostrzec zbliżenie w stosunkach francusko-brytyjskich. Nad Sekwaną zaczęto godzić się na warunki wysuwane przez Wielką Brytanię, a pierwszym asumptem ku temu było przyjęcie planu Dawesa oraz powolne wycofywanie oddziałów z Zagłębia Ruhry.

Po uregulowaniu sprawy kredytu $400 \mathrm{mln}$ na cele wojskowe Polsce udało się również zawrzeć 9 grudnia 1924 roku nową konwencję handlową. Ratyfikacja nastąpiła 10 lipca $1925 \mathrm{roku}^{28}$. Podpisanie wpłynęło dodatnio na zwiększenie obrotu wymiany

\footnotetext{
${ }^{26}$ Za M. Wołos, Alfred Chłapowski..., s. 136-138, Pierwsza rata kredytu została uzgodniona z początkiem stycznia 1924 r. W zamian za otrzymanie $100 \mathrm{mln}$, Polska zastawiła lasy pomorskie w rejonie Torunia. Kolejne $300 \mathrm{mln}$ franków miały być zabezpieczone w postaci lasów z rejonu Gdańska i Bydgoszczy oraz dochody płynące z kopalń Górnego Śląska, które Francuzi dzierżawili. Z czwartej raty zrezygnowano. Dopiero później podjęto negocjacje o jej przyjęciu.

27 Wołos M., Francja - ZSRR: Stosunki polityczne w latach 1924-1932, Toruń 2004, s. 19-35.

${ }^{28}$ AMAE, Pologne, vol. 249, Konwencja handlowa polsko-francuska, k. 133-143; Landau Z., Tomaszewski J., Od Grabskiego..., s. 275; Wo- $\quad$ łos M., Alfred Chłapowski..., s. 141.
} 
handlowej. Francja otrzymała po raz kolejny klauzulę największego uprzywilejowania, zaś Polska - taryfę minimalną na artykuły, które były przedmiotem eksportu do Francji. Ustalenia zawarte w dokumencie uzmysłowiły stronie polskiej, że w wymianie handlowej z Francją nie była ona traktowana na równi z Czechosłowacją, Belgią czy Niemcami. Oba kraje w tym czasie przeżywały okres prosperity, Francja wyrównała swoje straty w gospodarce, osiągając porównywalny poziom z 1913 rokiem, natomiast w Polsce ustabilizowała się sytuacja walutowa, rozbudowywano port w Gdyni. Beneficjentem poprawy sytuacji gospodarczej, jako efektu reform Władysława Grabskiego, stały się władze polskie po zamachu majowym ${ }^{29}$.

Można pokusić się o stwierdzenie, że ogólny bilans handlowy Polski z Francją był w okresie międzywojennym ujemny ${ }^{30}$. Oczywi-

${ }^{29}$ Wołos M., O Piłsudskim, Dmowskim i zamachu majowym. Dyplomacja sowiecka wobec Polski w okresie kryzysu politycznego 1925-1926, Kraków 2013, s. 124 151.

${ }^{30}$ Analizując wymianę handlową pomiędzy Polską a Francją, należy skonstatować, że wykorzystane źródła, głównie przez J. Landau i Z. Tomaszewskiego, w konfrontacji ze źródłami archiwalnymi nie są zgodne. Oba kraje niedokładnie prowadziły statystykę wymiany handlowej. $\mathrm{W}$ dniu dzisiejszym należy zatem postawić pytanie o wiarygodność prezentowanych w literaturze przedmiotu wyników badań, choćby dotyczących bilansu handlowego między oboma państwami. Przykładowo, w biografii Alfreda Chłapowskiego (Wołos M., Alfred Chłapowski.., s. 139, przyp. 175) autor powołuje się na ustalenia, że bilans handlowy Polski z Francją w 1923 r. był dodatni. Nie do końca przekonują one autorkę niniejszego artykułu. Oczywiście autor opiera swój wniosek na informacjach pochodzących z materiałów źródłowych, niemniej jednak należy bardziej pochylić się nad tym problemem. Autorka również dotarła do tych samych dokumentów Ambasady Polskiej w Paryżu, w których stwierdzono, iż bilans handlowy w 1923 r. był „wybitnie czynny”, ponieważ wywóz towarów polskich do Francji wyniósł ok. $143 \mathrm{mln}$ fr. a przywóz towarów francuskich do Polski ok. $91 \mathrm{mln}$ fr. Wywóz z Polski przewyższył prawie o $40 \%$ przywóz z Francji. Ambasada opierała się jedynie na danych sporządzonych przez stronę francuską. Czy należy nadmiernie wierzyć w te zestawienia liczbowe? Dlatego też należy zadać pytanie na jakiej podstawie przygotowywano analizy i obliczenia? Warto tu podkreślić, co będzie wyjaśnione w dalszej części tekstu, że Polska nie mając jeszcze do dys- 
ście wymiana handlowa między oboma krajami przybrała znacznie większe rozmiary, zwłaszcza po ratyfikowaniu - w 1925 r. - konwencji handlowej (1924 r.). Nie zmienia to jednak faktu, że Druga RP importowała w tym czasie więcej produktów z Francji, niż eksportowała (patrz tab.). Polsce udało się jedynie zwiększyć rozmiary eksportu węgla do Francji. Było to następstwem wypowiedzenia przez Niemcy wojny celnej w 1925 roku oraz strajku angielskiego w kopalniach w 1926 roku $^{31}$. W okresie kryzysu ekonomicznego, bilans oszacowano dla każdej ze stron na $150 \mathrm{mln}$ fr. francuskich. Francja głównie importowała węgiel, drzewo, konserwy, jarzyny, nasiona.

pozycji własnego portu, ani statków, korzystała z pomocy obcych państw, które dostarczały produkty na rynek francuski. To z kolei powodowało, że towar polski niejednokrotnie podlegał przepakowywaniu w portach tych państw. Czy był to wtedy jeszcze polski produkt? Nasuwa się tutaj kolejne pytanie: skoro polski produkt był przepakowywany, to kto ostatecznie czerpał profity z jego sprzedaży - eksporter, czy pośrednik? Na dzień dzisiejszy nie udało się ustalić tych informacji. Kolejna kwestia wiąże się z sytuacją ekonomiczną: Rzeczpospolita w 1923 roku przeżywała hiperinflację, zaś Francja poniosła straty finansowe, wynikłe z wkroczenia wojsk francuskich i belgijskich do Zagłębia Ruhry. Pomyślny wynik w wymianie handlowej przyniosła współpraca z Francją na polu artykułów włókienniczych, co jednak nie rzutowało w diametralny sposób na ogólny bilans. Z kolei należy pamiętać, iż fabryki w Łodzi, Częstochowie były spółkami francuskimi (przedsiębiorstwo Motte z siedzibą w Roubaix). Powyższy wywód posłużyć ma do podjęcia dalszych, pogłębionych badań. AAN, MSZ sygn. 3808, Ambasada RP do MSZ, uwagi w sprawie wymiany handlowej francusko-polskiej na podstawie bilansu francusko-polskiego za 1923 rok, Warszawa 23.I.1925 r., s. 12; Fronczek-Kwarta A., op. cit., s. 29.

${ }^{31}$ AAN, KRPM, sygn. 464/111, KRPM do MSZ, Możliwość importu węgla polskiego do Francji Południowej, Marsylia 3.VIII.1927 r., k. 1-3; Wroniak Z., Polityka Polska wobec Francji w latach 1925-1932, Poznań 1987, s. 48-49; Wołos M., Alfred Chtapowski...,s. 141; Kania K., Stosunki handlowe polsko-angielskie w latach 1918-1939, „Krakowskie Studia Małopolskie” 2006, nr 10, s. 13-18. 
Tab. Bilans handlowy Polski z Francją wyrażony w tys. zł. w złocie z $^{32}$

\begin{tabular}{|c|c|c|}
\hline Rok & Import & Eksport \\
\hline 1922 & 36397 & 11818 \\
\hline 1923 & 42956 & 24662 \\
\hline 1924 & 72639 & 52869 \\
\hline 1925 & 93932 & 21283 \\
\hline 1926 & 66572 & 47140 \\
\hline 1927 & 125744 & 24977 \\
\hline
\end{tabular}

CAW, O. II SG sygn. I.303.4.7447, Raport ekonomiczny za rok 1928. Stosunki handlowe polsko-francuskie, Lille 1928 r., s. 7.

Francuski system reglamentacyjny oraz polityka celna hamowały eksport polskich produktów. W tych okolicznościach władze w Warszawie usilnie dążyły do wynegocjonowania nowej konwencji handlowej. Należy dodać, że na przełomie lat 1927 i 1928 Francja borykała się z niewielkim kryzysem ekonomicznym, który jednak nie wywołał większych strat w gospodarce. W tym też okresie zaznaczył się spadek w wymianie towarów między krajami. Obie strony podjęły negocjacje, co zaowocowało podpisaniem nowej konwencji 24 kwietnia $1929 \mathrm{roku}^{33}$. Zredukowano taryfy celne - Polska obniżyła cła na francuskie towary żywnościowe, tekstylne, przemysłowe. Tym razem konwencja gwarantowała stronie polskiej klauzulę najwyższego uprzywilejowania. W tym czasie ambasador Alfred Chłapowski podpisał konwencję sanitarno-weterynaryjną, która określała warunki eksportu polskiego mięsa ${ }^{34}$. Konwencję ratyfikowała jedynie strona

${ }^{32}$ Sporządzone dane przez Konsulat w Lille zostały zaczerpnięte z Rocznika Statystyki Rzeczypospolitej Polskiej. „Rocznik Statystyki Rzeczypospolitej Polskiej” 1925/1926, nr 4, s. 112. Według danych podanych w pracy Z. Landau, J. Tomaszewskiego, Gospodarka Polski...T. II, s. 294, Polska w 1924 r. importowała na sumę 72,8 mln złotych, eksportowała 52,9, zaś w 1927 r. suma w eksporcie wynosiła 43 mln złotych, a w imporcie 216,3 mln złotych. Według czasopisma „Przemysł i Handel” eksport do Francji wyniósł 16088 tys. fr. szw. „Przemysł i Handel” 1923, z. 50-51.

${ }^{33}$ AMAE, Pologne, vol. 397. Umowę handlową podpisano 24 kwietnia $1929 \mathrm{r}$.

${ }^{34}$ Wołos M., Alfred Chłapowski..., s. 199. 
polska, francuski parlament ją odrzucił. Dopóki Polska mogła korzystać z przyznanych ulg celnych, poczyniono kroki w celu sprowadzenia transportu 300 szynek w puszkach przez firmę „Compagne Franco - Orientale" "35. Akcja ta zakończyła się fiaskiem, gdyż długi czas transportu i niewłaściwe zabezpieczenie mięsa doprowadziły do jego zepsucia.

Na przełomie lat 20. i 30. widoczne było ochłodzenie się stosunków polsko-francuskich. Francja prowadziła defensywną (ustępliwą) politykę wobec Niemiec, a jej wyrazem była konferencja w Locarno, która uświadomiła z kolei stronie polskiej, że nie jest traktowana jak równorzędny partner. Kropką nad i okazała się Konferencja Rozbrojeniowa, która potwierdziła fakt nieliczenia się nad Sekwaną ze stanowiskiem wschodniego alianta. Dlatego też Marszałek Józef Piłsudski zaczął realizować koncepcję polityki równych odległości wobec Niemiec i ZSRR ${ }^{36}$.

Lata trzydzieste to bez wątpienia najtrudniejszy okres w polsko-francuskich stosunkach gospodarczych. Wielka fala kryzysu zapoczątkowana w Stanach Zjednoczonych w 1929 r., dotknęła także Francję, choć później, bo w 1931 r. rząd polski stanął przed obliczem szukania nowych możliwości eksportu rodzimej produkcji. Z kolei Trzecia Republika zaczęła sukcesywnie wprowadzać politykę kontyngentową ${ }^{37}$. Od 1931 r. Warszawa prowadziła z Paryżem kolejne

\footnotetext{
${ }^{35}$ AAN, KRPM, sygn. 464/52, KRPM do MSZ, import wyrobów masarskich, Marsylia 13.XII.1929 r., k. 167-168.

36 Zob. Korczyk H., Działanie i recepcja Locarna 1927-1936, Warszawa 1999; Bułhak H., Polska - Francja z dziejów sojuszu 1933-1936, Warszawa 2000, s. 9-14; Kuźmiński T., Polska, Francja, Niemcy 1933-1935. Z dziejów sojuszu polsko-francuskiego, Warszawa 1963, s. 40-89; Polska polityka zagraniczna w latach 1926-1932. Na podstawie tekstów min. Józefa Becka, oprac. A. Cienciała, Paryż 1990, s. 68-75; Kornat M., Polityka zagraniczna Polski 1938-1939. Cztery decyzje Józefa Becka, Gdańsk 2012, s. 16-25.

${ }^{37}$ Społeczeństwo francuskie, w obawie przed złą kondycją gospodarczą kraju, zamrażało swoje oszczędności, a to z kolei powodowało wycofanie z obiegu pieniądza. Eksport win i towarów luksusowych zmniejszył się, zaś kapitały zagraniczne kurczyły się. Francja pokrywała deficyt budżetowy ze sprzedaży akcji papierów
} 
rokowania handlowe. Reprezentant francuskiego przemysłu motoryzacyjnego - firma Renault a później Citroën - zainteresowały się rynkiem polskim. To zainteresowanie wywołało konkretne działania ze strony polskiej, która wystąpiła z propozycją uzyskania od Francuzów kredytu z przeznaczeniem na zakup samochodów, jednak go nie uzyskała. W tej sytuacji podjęto negocjacje z włoskim Fiatem, co zaskutkowało podpisaniem umowy. 12 sierpnia 1932 r. Polska i Francja podpisały protokół do konwencji z 1929 r., który mówił o wzajemnym udzieleniu kontyngentów w stosunku 1:138. Niestety, Polska wprowadziła w niedługim czasie nową taryfę celną, która znacznie podnosiła stawki dla wszystkich artykułów francuskich, co spowodowało, że protokół z 1932 r. przestał obowiązywać, a jedyną gwarancją w stosunkach polsko-francuskich był traktat handlowy z 1924 roku. Od Francji uzyskano ostatnią - czwartą ratę kredytu na cele wojskowe w lutym 1931 roku. Polityka kontyngentowa odbiła się echem we francuskiej prasie ekonomicznej. W „Le Sémaphore” napisano, że trzeba dobrej woli (...) należy tylko umieć zastosować politykę kontyngentowa $w$ stosunku do naszych aliantów i do interesów politycznych (...) $)^{39}$.

Jak słusznie zauważył Mariusz Wołos, stosunki gospodarcze polsko-francuskie były odbiciem stosunków politycznych ${ }^{40}$. Prowadzone gry dyplomatyczne nad Wisłą i Sekwaną (Pakt Czterech, podpisanie deklaracji o niestosowaniu przemocy 26 stycznia 1934 r., pakt wschodni, ratyfikacja paktu francusko-radzieckiego, remilitaryzacja Nadrenii)

wartościowych. AAN, Sztab Główny, sygn. 616/48, płk dypl. J. Błeszyński do szefa Oddz. II Sztabu Głównego w Warszawie, 14.II.1933 r., k. 665-674.

${ }^{38}$ P D D 1932, dok. 212, s. 485-486; Wołos M., Alfred Chtapowski..., s. 200-201; Zjazdy i konferencje... dok. 30, s. 350; Landau Z., Tomaszewski J., Gospodarka Polski międzywojennej 1918-1939, T. III., s. 383-384.

${ }^{39}$ AAN, KRPM, sygn. 464/275, KRPM do ARPP znamienne artykuły w sprawie stosunków handlowych polsko-francuskich, Marsylia 12.V.1934 r., k. 5-6; Wołos M., Alfred Chtapowski..., s. 264.

${ }^{40}$ Ibidem, s. 268. 
naruszały zasady wzajemnego zaufania. Obie strony zdawały sobie sprawę z faktu, że utrzymanie sojuszu z 1921 r. było konieczne. Polska w tym czasie podejmowała próby uzyskania od sojuszniczki pożyczek inwestycyjnych. Pertraktacje zostały zwieńczone uzyskaniem kredytu w wysokości 50 mln złotych, natomiast nie udało się uzyskać znacznie większego kredytu na cele zbrojeniowe. Ponadto oba kraje w dalszym ciągu łączyła dość delikatna i niewyjaśniona sprawa związana z zakładami żyrardowskimi ${ }^{41}$. Nad Wisłą przyglądano się nowym wyborom parlamentarnym we Francji, które odbyły się wiosną 1936 roku. Dotychczas we francuskich kołach rządowych dochodziło w szybkim tempie do zmiany szefów rządu. Szala zwycięstwa w wyborach przechyliła się na stronę Front Populaire, na którego czele stał Leon Blum. Wybór nowych władz we Francji zmienił optykę rządu polskiego. Władze w Warszawie uznały bowiem, że nadarza się okazja, by spróbować zmienić charakter stosunków dwustronnych. Skierowano na placówkę dyplomatyczną do Paryża Juliusza Łukasiewicza - znawcę problematyki wschodniej, ale także zaufanego Józefa Becka ${ }^{42}$. Tuż po wyborach, 9 maja 1934 r. Polska wypowiedziała obowiązującą konwencję handlową z 1924 roku $^{43}$. Akcja ta miała na celu przyspieszenie nawiązania nowych negocjacji handlowych. Konsekwencją gry władz polskich było podpisanie układu handlowego 20 lipca 1936 roku. Wymiar kontaktów ekonomicznych

\footnotetext{
${ }^{41}$ Ambasador Polski Alfred Chłapowski podpisał z rządem francuskim układ gospodarczy dotyczący zakładów żyrardowskich. Sprawa zakładów w ogólnym rozrachunku rzutowała negatywnie na stosunki polsko-francuskie. Właścicielem zakładów był Francuz - Marcel Boussac. Przejął on zarząd w sierpniu 1923 r. Od tego roku Boussac prowadził w zakładach „kreatywną księgowość”, która przyczyniła się do ich zrujnowania. Patrz Landau Z., Tomaszewski J., Kapitały obce..., s. 117-131; idem, Sprawa żyrardowska: przyczynek do dziejów kapitałów obcych w Polsce międzywojennej, Warszawa 1983; Wołos M., Alfred Chłapowski..., s. 201. 42 Łukasiewicz J., Dyplomata w Paryżu 1936-1939: wspomnienia i dokumenty Juliusza Łukasiewicza ambasadora Rzeczypospolitej Polskiej, oprac. W. Jędrzejewicz, H. Bułhak, Londyn 1989, s. 23-24; Kitchen M., Historia Europy 1919 1939, Wrocław 2009, s. 390-391.

${ }^{43}$ Landau Z., Tomaszewski J., Lata interwencjonizmu..., s. 488-489.
} 
wzmocniły podjętew Rambouillet zobowiązania sfer wojskowych ${ }^{44}$. Polska zagwarantowała Francji, a także Algierii 90\% przywozu francuskich towarów. Polska mogła eksportować $70 \%$ produktów ${ }^{45}$. Dodatkowo Francja pozwoliła na wywóz materiałów włókienniczych, kakao, rumu i ryżu z jej kolonii. Ważną kwestią w eksporcie produktów kolonialnych do Polski była sprawa wystawiania odpowiedniego świadectwa pochodzenia towaru. Dla lepszego zobrazowania tej sytuacji niech posłuży przykład importu wanilii do Polski. Otóż produkt ten skupowany przez francuskich kupców z kolonii, był przez nich sortowany i przepakowywany, co w konsekwencji prowadziło do obniżenia jego wartości. Pomimo że Francja była eksporterem produktów kolonialnych, polski urząd celny nie przyjmował towarów z wystawionym świadectwem pochodzenia z kolonii.

Zacieśnienie współpracy gospodarczej nastąpiło po podpisaniu przez obie strony traktatu handlowego i układu płatniczego dnia 22 maja 1937 roku, który został uzupełniony dodatkowym układem z 27 marca 1939 roku, a wszedł w życie 1 maja 1939 roku. W ramach dotychczas obowiązujących przepisów, eksport towarów francuskich do Polski nie mógł stanowić więcej niż 80\% wartości eksportu polskiego do Francji. W tym okresie zauważalna była tendencja spadkowa w zakresie eksportu polskich produktów, co z kolei pociągało za sobą jednoczesny spadek wartości eksportu francuskiego. To w konsekwencji doprowadzało do faktycznego zamrożenia obrotów handlowych między obu krajami. Aby temu zjawisku zaradzić, wprowadzono zapis o transakcjach wiązanych, które nakładały obowiązek wyrównania eksportu z Polski do Francji tych samych produktów, sprowadzanych do kraju (tzw. kompensacja). Sporządzono listy produktów, towarów i surowców podlegających temu procesowi. Identyczna sytuacja wy-

${ }^{44}$ Bułhak H., op. cit., s. 142-146; Beck J., Wspomnienia o polskiej polityce zagranicznej 1926-1939, oprac. A. Cienciała M., Warszawa-Kraków 2015, s. $163-$ 165.

${ }^{45}$ AAN, KRPM, sygn. 464/262, KRPM do MSZ w sprawie układu handlowego z 20 lipca 1936 r., Marsylia 18.IX.1936 r., k. 111. 
stąpiła w przypadku eksportu towarów francuskich do Polski. Zmiany miały obowiązywać od 1 maja 1939 roku, a nadzór nad ich sprawnym wdrożeniem powierzono dwóm firmom: Polskiemu Towarzystwu Handlu Kompensacyjnego - Zahan i Comité de Coordination przy Izbie Handlowej Polsko-Francuskiej w Paryżu. Podjęte decyzje nie dotyczyły obrotu handlowego Polski z francuskimi koloniami, krajami mandatowymi i protektoratami, a przypadki występowania kompensacji miały być rozpatrywane indywidualnie.

Polska w tym czasie poszukiwała dogodnych warunków umożliwiających sprawną wymianę handlową przede wszystkim drogą morską. Nie bez znaczenia okazało się powołanie do życia placówki konsularnej RP w największym porcie południowej Francji-Marsylii. Zdanie pochodzące z jednego z dokumentów Komitetu Narodowego Polskiego w Paryżu Port o bardzo wielkim w przyszłości dla Polski znaczeniu handlowym, przyczyniło się do wskazania tego ośrodka miejskiego jako jednego z celów na mapie tworzonej sieci konsularnej we Francji ${ }^{46}$. Port marsylski, jako największy we Francji, odgrywał znaczącą rolę w jej handlu zagranicznym. Jak napisał Leszek Gustowski leży na skrzyżowaniu trzech najważniejszych dróg morskich globu (Suez-Gibraltar-Panama). (...) pozostanie naturalna brama wypadowa do kolonii zamorskich Francji ${ }^{47}$. Długość nabrzeża portu marsylskiego wynosiła $26187 \mathrm{~km} \mathrm{z} \mathrm{czego} \mathrm{na} \mathrm{strefę} \mathrm{przeładunkową}$ przypadało $18742 \mathrm{~km}$. To właśnie w nowoczesnej części portu skupiało się życie handlowe. Położony bardziej na wschód, stary port nie miał większego znaczenia. Był to port rybacki, do którego zawijały

\footnotetext{
${ }^{46}$ AAN, Komitet Narodowy Polski [dalej: KNP], sygn. 171, Projekt sieci polskich placówek konsularnych we Francji, Anglii, Belgii, Szwajcarii, Włoszech, Hiszpanii oraz prowizoryczny budżet tych na II półrocze 1919 r. Francja, Paryż, IV.1919 r., k. 67; Polskie Dokumenty Dyplomatyczne 1918, pod red. S. Dębskiego, Warszawa 2008, dok. 117: [po 12 grudnia] notatka Wydziatu Konsularnego MSZ w sprawie utworzenia sieci konsularnej, s. 233-236.

${ }^{47}$ L. Gustowski, Od Warszawy do Sahary. Opisy, wrażenia i studia podróżnicze, Poznań 1932, s. 33.
} 
małe statki handlowe ${ }^{48}$. Marsylia miała stałe połączenia z ponad 100 portami na świecie dzięki 80 regularnym liniom, obsługiwanym przez francuskie statki oraz 85 liniom obsługiwanym przez statki innych krajów $^{49}$. Ważną rolę dla portu marsylskiego odgrywały tzw. aneksy - porty pomocnicze, położone przy kanale łączącym port z Rodanem: Port-de-Bouc, Martiques, Berre, Caronte, La Mède, Lavèra. Największe zróżnicowanie obrotów towarowych miał Port-de-Bouc. Najczęściej rozładowywano w nim węgiel, ropę, rudy żelaza, nasiona oleiste, a wywożono cement i boksyt. Do pozostałych aneksów przywożono ropę naftową ${ }^{50}$. Za ustanowieniem konsulatu przemawiały także inne względy - konsulat w Marsylii miał za zadanie nadzorowanie powstającej sieci konsulatów honorowych, które ustanawiano w miastach portowych ${ }^{51}$. Nie można oprzeć się stwierdzeniu, że port marsylski był oknem na świat, nie tylko dla obrotu towarami, ale także był przepustką dla cudzoziemców, jako przystanek w ich podróży lub docelowe miejsce. Placówka marsylska działała aktywnie na polu życia ekonomicznego, nawiązując kontakty z wpływowymi osobami w świecie biznesu, przedsiębiorcami i przedstawicielami handlowymi. Dobór odpowiedniej kadry konsularnej ułatwiał w znacznym stopniu realizację owych przedsięwzięć, zwłaszcza w odniesieniu do placówek honorowych.

Pracownicy tych konsulatów, których obszar kompetencyjny rozciągał się na francuskie porty - Hawr, Dunkierka, Bordeaux, bacznie obserwowali rynek miejscowy i swoje spostrzeżenia przekazywali w sprawozdaniach ekonomicznych do Ministerstwa Spraw Zagranicz-

48 AAN, KRPM, sygn. 464/869, Port marsylski z aneksami w 1937 r., Marsylia 29.III.1938 r., k. 173-174.

${ }^{49}$ AAN, KRPM, sygn. 464/38, Położenie Marsylii a jego stopień wykorzystania, Marsylia 19.IV.1938 r., k. 4.

${ }^{50}$ AAN, MSZ, sygn. 4019, KRPM do MSZ w sprawie obrotów handlowo-morskich w Marsylii w 1935 r., Marsylia 3.IV.1936 r., k. 22.

${ }^{51}$ Ambrochowicz-Gajownik A., Powstanie Konsulatów Honorowych II RP w Afryce Północnej-wybrane problemy, „Dzieje Najnowsze” 2012, nr 3, s. 3-19. 
nych. Najważniejszym zadaniem była reklama polskich produktów oraz nawiązywanie kontaktów z miejscowymi środowiskami gospodarczymi. Zdarzały się przypadki wychodzenia z własną inicjatywą w celu zbliżenia do lokalnych przedsiębiorców, tak jak to uczynił Tadeusz Nieduszyński - kierownik placówki marsylskiej - założył on własną działalność gospodarczą i próbował przekonać francuskich przedsiębiorców do zakupu polskiego drewna ${ }^{52}$. Przy okazji nawiązywania kontaktów, pojawiały się nowe problemy. Pierwszą istotną kwestią była niewypłacalność polskich przedsiębiorców. Następnym palącym problemem była sprawa przewozu polskich towarów, a za tym piętrzyły się kolejne niedogodności.

Wymiana handlowa pomiędzy Polską a Francją odbywała się w większości drogą morską. Powstało Konsorcjum Polsko-Francuskie, a zaangażowanie finansowe strony francuskiej przyczyniło się do uruchomienia linii morskiej Gdynia - Hawr ${ }^{53}$. Połączenie to umożliwiło w znacznym stopniu dostarczanie drogą morską polskich towarów, jednakże nie spowodowało wzrostu obrotu wymiany handlowej. Towary polskie, zanim trafiły do francuskich portów, przeładowywane były w portach państw, z którymi Polska miała podpi-

${ }^{52} \mathrm{~W}$ pierwszej połowie lat dwudziestych konsulat marsylski w głównej mierze skupiał się na sprawach gospodarczych. Wynikało to zarówno z gospodarczego znaczenia miasta i portu, jak i ewentualnych korzyści, jakie mogły przynieść polskim firmom konkretne informacje na temat polityki gospodarczej Francji wobec południowych terenów państwa i kolonii zamorskich. Działania placówki kontrastowały z aktywnością innych placówek konsularnych, które miały skupiać się na pracach administracyjno-obserwacyjnych i opiece nad wychodźstwem oraz traktować sprawy gospodarcze jako uzupełniające, zob. W. Skóra, op. cit, s. 624, przyp. nr 3. Tak sformułowany wniosek przez radcę T. Nieduszyńskiego musi budzić wątpliwości, ponieważ on sam, jako kierownik placówki w Marsylii, podkreślił w sprawozdaniu z 1923 roku swój wysoki stopień zainteresowania rozwojem stosunków handlowych między firmami polskimi a francuskimi oraz algierskimi na rynku drzewnym. Pośredniczył w nawiązywaniu kontaktów między przedstawicielami tych firm, podróżował w tym celu do Polski i Algierii, zwracał uwagę na różnego rodzaju trudności występujące przy tego rodzaju działalności, AAN, KRPM, sygn. 464/697, KRPM do MSZ, Marsylia 6.III.1923 r., k. 2-9.

${ }^{53}$ Polska-Francja..., s. 424; AMAE, Pologne, vol. 129, k. 138-140. 
sane umowy czarterowe. Polskie towary trafiały na rynek francuski w głównej mierze na statkach firmy „Worms et Cie” niemieckich kompanii - „Deutsche Levante-Linie”, „Svenska Lloyd” oraz amsterdamskich ${ }^{54}$. Czas przeładunku niejednokrotnie przedłużał się, co wpływało ujemnie na utrzymanie jakości niektórych produktów i na wizerunek polskich firm ${ }^{55}$. Uzależnienie od obcych firm przysparzało wielu problemów stronie polskiej, o czym będzie jeszcze mowa. Drogą lądową sprowadzano z Francji jedynie oleje i wyroby kolonialne, jednakże transport ten był nieopłacalny. Placówki konsularne w swych sprawozdaniach apelowały do władz zwierzchnich o uruchomienie bezpośredniej linii Gdynia - Hawr, obsługiwanych przez statki pod polską banderą, w celu ułatwienia i usprawnienia dostaw towarów ${ }^{56}$.

Sytuacja się poprawiła, gdy Polska złożyła zamówienie na budowę statków handlowych we francuskiej stoczni Chantiers Navals Français w 1925 roku $^{57}$. Pod polską banderą pływały statki noszące nazwy: SS Wilno, SS Toruń, SS Poznań, SS Katowice, SS Kraków ${ }^{58}$. Kursowały po Morzu Bałtyckim i Północnym, jednak żaden z nich nie zawiną do portu marsylskiego. W Dunkierce wyładowywano polskie drewno, do Roubaix trafiały towary włókiennicze, a do Calais koronki i tiule. Głównym i zarazem najważniejszym produktem eksportowym był węgiel, który po wojnie celnej z Niemcami zaczął cieszyć się we Francji powodzeniem. Do 1928 roku niewielkie ilości węgla polskiego

\footnotetext{
${ }^{54}$ AMAE, Pologne, vol. 245, Nota o firmie i jej połączeniach międzynarodowych, k. 7 .

${ }^{55}$ AAN, KRPM, sygn. 464/50, Marsylia - ważny etap dla naszej ekspansji eksportowej, Marsylia 16.III.1927 r., k. 36-38; France - Pologne, „Le Sémaphore Algerien" nr 988 z 24.07.1919.

${ }^{56}$ AAN, KRPM, sygn. 464/50, Gdynia - Marsylia, opracowanie referenta handlowego - dra Stanisława Reicha, Marsylia [bdw], k. 168.

${ }^{57} \mathrm{~W}$ tym samym czasie Polska złożyła zamówienie na statki podwodne i niszczyciele. Te drugie zostały zbudowane w stoczni Chantiers Naval Français, zaś pierwsze w stoczni Chantiers et Ateliers Augustin Normand w Hawrze, za M. Wołos, Alfred Chtapowski..., s. 142-143.

${ }^{58}$ Piwowoński J., Flota spod biało-czerwonej, Warszawa 1989, s. 17-18.
} 
trafiły do portów w Rouen, Hawrze, Dunkierce. Do Marsylii pierwszy transport trafił na przełomie 1928 i 1929 roku. Do portu w Nicei przywieziono ok. 30 tys. ton węgla polskiego ${ }^{59}$. Największe ilości wyładowywano w Pas-de-Calais, dzięki firmie francuskiej, mającej swoje udziały w Skarbofermie. Polska dostarczała na rynek francuski drewno, jednak jego ceny były zbyt wysokie w porównaniu ze skandynawskimi oraz rosyjskimi i ostatecznie Francja zaprzestała importować ten produkt. Kolejnym towarem cieszącym się powodzeniem był cukier. Polska eksportowała do Francji 308507 kwintali. Sytuacja uległa zmianie, gdy rodzima produkcja zaczęła zaspokajać własny rynek. Z raportów konsularnych wynika, że od lat 30 . statki „Żeglugi Polskiej” nie zawijały do portów północnej Francji. Aby zaradzić wciąż malejącej wymianie handlowej Polsko-Brytyjskie Towarzystwo Okrętowe (Polbrit) postanowiło nawiązać współpracę z kompaniami „Transatlantique” i „Royal-Mail-Line”60. Linie te przewoziły od 1935 r. na statku „Warszawa” emigrantów z Polski do Hawru i Cherbourga. Towarzystwo uzgodniło, że prócz przewozu polskich emigrantów, statki będą przewoziły polskie i francuskie towary. Kursy zaplanowano z półrocznym wyprzedzeniem, co pozwalało na określenie warunków transportu towarów. Ponadto dzięki temu, francuskie firmy miały pewność, że towar nadejdzie w określonym terminie $^{61}$. Dużym sukcesem Polska mogła się poszczycić w 1937 r.,

\footnotetext{
${ }^{59}$ Jednak już w 1936 roku zapotrzebowanie spadło do 12 tys. ton. Natomiast z Nicei importowano do Polski oliwę, perfumy, kwiaty cięte. W ogólnym rozrachunku Port w Nicei miał charakter lokalny, więc dla wymiany międzynarodowej nie miał żadnego znaczenia. Nicejskie sfery gospodarcze nie były zainteresowane polskimi produktami. Pierwszym produktem polskim, jaki trafił na rynek nicejski, był węgiel. Od czerwca 1928 roku, produkt ten cieszył się dużym zainteresowaniem ze względu na jakość i konkurencyjną cenę. Wyparł z rynku angielski i belgijski. AAN, KRPM, sygn. 758, Raport administracyjny za rok 1932 r., Nicea 23.I.1933 r., k. 217-218.

${ }^{60}$ Piwowoński J., op. cit., s. 41-47.

${ }^{61}$ AAN, KRPM, sygn. 464/869, Raport attache handlowego Ambasady RP w Paryżu dotyczący stosunków morskich polsko-francuskich, Paryż [brak daty], s. 353-374.
} 
kiedy to w porcie marsylskim zacumował pierwszy polski statek SS „Kraków” z 925 tys. ton węgla pod pokładem ${ }^{62}$.

Polsko-francuskie obroty handlowe były uwzględniane we francuskich statystykach dopiero od 1926 r. Polska również zaniedbała tę kwestię $^{63}$. We Francji zestawieniami obrotów handlowych zajmowały się dwa niezależne organy: zarząd portu podlegający dyrekcji dróg i mostów przy Ministerstwie Robót Publicznych i okrętowa dyrekcja celna podlegająca Ministerstwu Skarbu. Następnie francuskie Izby Handlowe publikowały całokształt wymiany handlowej. Zarząd portu opracowywał dane, ale tylko pod względem ruchu okrętowego. Informacje te były zazwyczaj niedokładne, opierały się na zeznaniach kapitanów statków. $Z$ kolei dyrekcja celna uwzględniała inne porty i ruch handlowy drogą lądową. Wiele towarów było nierejestrowanych, gdyż pochodziły z nielegalnego przemytu, jak broń i narkotyki. Towary polskie figurowały zazwyczaj w zestawieniach jako ,inne kraje" lub też przypisane były tym państwom, od których czarterowały swoje statki. Dużym utrudnieniem jest określenie dokładnych danych statystycznych, które określałyby faktyczny obrót towarami.

W związku z prowadzoną polityką kontyngentową Francji, Polska poszukiwała nowych dróg dla eksportu własnych produktów. Zwrócono uwagę na kolonie i protektoraty francuskie. Z racji skromnych środków finansowych, które mogły być przeznaczone na rozwój sieci konsularnej, polski MSZ decydował się na tworzenie, na istotnych z punktu widzenia gospodarczego terytoriach, placówek konsulatów honorowych. Ich kierownikami byli Francuzi, wpływowi przedsiębiorcy, dzięki którymi rozwijała się wymiana handlowa. Nadzór nad powstałymi placówkami powierzono konsulatowi w Marsylii. Do każdego konsulatu honorowego przydzielano pracownika

\footnotetext{
${ }^{62}$ AAN, MSZ, sygn. 2626, KRPM do MSZ, w sprawie obrotów portowych w Marsylii w 1936 r., Marsylia, 21.IV.1936 r., k. 49.

${ }^{63}$ CAW, O. II SG sygn. I.303.4.7447, Raport ekonomiczny za rok 1928. Stosunki handlowe polsko-francuskie, Lille $1928 \mathrm{r}$.
} 
kontraktowego, który jednocześnie współpracował z Państwowym Instytutem Eksportowym.

Administracja i przepisy celne w poszczególnych koloniach wpływały na charakter i wartość wymiany handlowej. Ważnymi czynnikami, uwzględnianymi w procesie planowania eksportu i importu, było położenie ośrodka miejskiego, warunki klimatyczne, stopień zaludnienia. Przepisy celne pomiędzy Francją a jej koloniami uregulowane były ustawą z 13 kwietnia 1928 r., jednakże każde państwo pobierało różne stawki za towary. Algieria stanowiła jednolite terytorium z Francją pod względem celnym ${ }^{64}$. Z punktu widzenia interesów ekonomicznych państwa polskiego, cennym partnerem w wymianie handlowej było Maroko, gdyż władze gubernatorskie nie prowadziły polityki kontyngentowej ${ }^{65}$. Kolonie w Afrique Occidentale Française (A.O.F) miały autonomię administracyjną i finansową, choć pozostawały pod kontrolą administracji centralnej i generalnego gubernatora grupy kolonii A.O.F ${ }^{66}$. W Afryce Zachodniej polityka celna nie była uzależniona od umów z Francją, zaś na Madagaskarze oraz w Indochinach obowiązywała francuska taryfa celna. Produkty takie jak bawełna i jedwab objęte były polityką kontyngentową. W Afryce Północnej największymi ośrodkami wymiany handlowej były Algieria i Maroko ${ }^{67}$, zaś w Afryce Zachodniej - Dakar. W handlu zagranicz-

\footnotetext{
${ }^{64}$ AAN, KRPM, sygn. 464/10, KHRPA do KRPM w sprawie ogólnych warunków importu do Algieru, Algier 28.III.1936 r., k. 268-271. Wyjątki w pobieraniu opłat celnych odmiennych niż w metropolii stanowiły produkty takie jak: mięso, cukier, kawa, tytoń.

${ }^{65}$ W 1933 roku Francja, będąc związana unią celną z Tunezją, podwyższyła cła na konfekcję sprowadzaną z Polski do Tunezji. AAN, KRPM, sygn. 464/23, KRPM do MSZ, Sprawozdanie ekonomiczne, opracował referent handlowy Konsulatu RP w Marsylii, A[ntoni - AAG] Marczyński, Marsylia, 26.VI.1935 r., k. 3-8.

${ }^{66}$ AAN, KRPM, sygn. 464/12, Sprawozdanie Antoniego Marczyńskiego - referenta handlowego Konsulatu RP w Marsylii z pobytu w Dakarze za czas 27.04.1935 18.05.1935 r., Marsylia 8.VI.1935 r., k. 122-128; AAN, KRPM, sygn. 464/13, Józef Mańkowski do KRPM w sprawie Gwinei Francuskiej, Konakry 25.VIII.1937 r., k. 13. ${ }^{67}$ AAN, KRPM, sygn. 464/16, KRPM do MSZ w sprawie portu w Casablance, Marsylia 18.VI.1932 r., k. 70-71; AAN, MSZ, sygn. 3717, KRPM do MSZ
} 
nym Dakaru znaczącą rolę odgrywały domy handlowe mające swoje siedziby w Marsylii, Bordeaux i Paryżu.

Informacje o wymianie gospodarczej między Polską a koloniami francuskimi przeważnie zamieszczane były w drukach Głównego Urzędu Statystycznego w Paryżu. Raporty ekonomiczne sporządzane przez pracowników konsulatów honorowych opierały się na francuskich zestawieniach ${ }^{68}$. Lokalne władze nie wyodrębniały produktów polskich, ze względu na małe rozmiary eksportu ${ }^{69}$. Polska wymiana handlowa widniała pod nazwą , inne kraje" "70. Maroko, Tunis i Syria miały regularne połączenie z Polską, dzięki współpracy z obcymi firmami. W dalszym ciągu produkty przeładowywano w portach w Kopenhadze, Hamburgu, Antwerpii, zanim trafiły na rynek kolonii. Uruchomienie połączeń bezpośrednich do kolonii francuskich było niedochodowe. Strona polska - Główny Urząd Statystyczny - wyodrębniała informacje o eksporcie do kolonii dopiero od 1935 roku. Państwowy Instytut Eksportowy w wydawanym „Informatorze Eksportowym" publikował rozmiary wymiany handlowej z Francją i jej koloniami. Warto nadmienić, że towary polskie kierowane do

w sprawie rozwoju portów marokańskich, Marsylia 29.XII.1930 r., k. 15-23. AAN, KRPM, sygn. 19, Charakterystyka Tunisu, k. 28-61.

${ }^{68}$ AAN, KRPM, sygn. 464/580, Polsko-Francuska Izba Handlowa w Warszawie do KRPM, Warszawa 8.II.1934 r., k. 68-69. Informacje czerpane były z „La Journée Industrielle".

${ }^{69}$ „Bulletin de l'Agence Générale des Colonies” nr 221 z 02.1927, s. 261-262.

${ }^{70} \mathrm{~W}$ Maroku wymiana handlowa z Polską uwzględniania była dopiero od $1932 \mathrm{r}$. Prowadziło je Biuro Statystyczne w Casablance. Dane były zamieszczane w oficjalnych wydawnictwach: „Bulletin Comparatif Trimestriel”, „Statistique du Mouvement Commercial et Maritime du Maroc". Na żądanie Protektoratu biuro to sporządzało raporty statystyczne. AAN, KRPM, sygn. 17, KHRPC do KRPM w sprawie obrotów handlowych w Maroku, Casablanca 24.I.1934 r., k. 6-7; Konsulat w Tunisie opierał się na statystykach Dyrekcji Ceł oraz z „Bulletin de la Chambre de Commerce Française de Tunis". AAN, KHRPT, sygn. 1, KRPM do KHRPT, Marsylia 17.XII.1932 r., k. 36; Statystyki obrotu Polski i Madagaskaru ukazywały się w „Journal officiel de Madagascar”, AAN, KHRPTan, sygn. 2, KHRPTan do KRPM, Tananariwa 19.XII.1938 r., k. 83-84. 
kolonii często przechodziły przez port marsylski. Zdarzały się przypadki, że produkty te miały przypisywane pochodzenie francuskie.

Ogólny eksport towarów polskich do posiadłości zamorskich w 1935 roku oszacowano na 20 mln franków francuskich, suma ta była znacznie skromniejsza w porównaniu z ogólnym importem z kolonii francuskich wahającym się w granicach 9 mld fr. francuskich. Nie zmienia to jednak faktu, iż największymi odbiorcami produktów polskich był protektorat Maroka - drzewo i wyroby z drewna, dykty, wyroby włókiennicze, cukier, przetwory mięsne oraz mandat Syrii i Libanu - za sprawą uruchomienia ponownej linii lewantyńskiej - importujący wyroby włókiennicze, dykty, cukier, żelazo, wyroby z żelaza ${ }^{71}$. Na kolejnym miejscu plasowała się Algieria, dokąd eksportowano węgiel kamienny i drzewo. Drewno było objęte kontyngentem, jednakże Generalne Gubernatorstwo Algierii wyraziło zgodę na jego import. W dalszej kolejności Tunis importował przetwory mięsne, dykty, wyroby szklane i ceramiczne, fasolę. Łączna wartość importu z Polski wyniosła $15 \mathrm{mln}$ franków. Pozostałe $5 \mathrm{mln}$ przypadło na inne kolonie francuskie, między innymi na Dakar, tylko dlatego że firma założona przez konsula honorowego zgłaszała zapotrzebowanie na różnego rodzaju produkty. Do Afryki Zachodniej z Senegalem na czele, trafiały wyroby emaliowane, krzesła, szynka w puszkach. Do pozostałych kolonii towary polskie były dostarczane w mniejszych ilościach, ze względu na braki komunikacyjne. Od 1934 roku na Madagaskar wysyłano polskie metalowe naczynia, meble gięte oraz od 1936 roku konserwy mięsne. Natomiast Polska sprowadzała

71 AAN, KRPM, sygn. 464/18, Agencja konsularna RP w Bejrucie do KRPM w sprawie polsko-syryjskich obrotów handlowych w 1936 r., Bejrut 28.IV.1937 r., k. 99-109. Stosunki handlowe z Syrią i Libanem do 1937 r. były tylko jednostronne. Ibidem, Bejrut 8.IV.1938 r., k. 83-96; „Żegluga Polska” w porozumieniu ze szwedzką kompanią „Svenska-Orient-Line” podpisały porozumienie w sprawie uruchomienia bezpośredniej linii z Gdyni do Lewantu z postojem w Dunkierce. AAN, KRPM, sygn. 464/869, Raport attache handlowego Ambasady RP w Paryżu dotyczący stosunków morskich polsko-francuskich, Paryż [brak daty], s. 353-374. 
z kolonii produkty spożywcze: ryż, kawę, herbatę, przyprawy, figi, daktyle, rodzynki ${ }^{72}$.

W latach 30. w Polsce uwidoczniła się prowadzona na szeroką skalę przez Ligę Morską i Kolonialną (LMiK) akcja „kolonizatorska”. Całe przedsięwzięcie ukierunkowane było na pozyskanie dla Polski terytoriów zamorskich, służących rozwojowi gospodarczemu. Liga morska wykorzystała moment niekorzystnej sytuacji wewnętrznej w Liberii, która utrzymywała oficjalnie status państwa niepodległego ${ }^{73}$. Gdy jesienią 1934 roku do Warszawy przybył liberyjski przedstawiciel, dr Leo Sajour, który zwrócił się do Ligi Morskiej i Kolonialnej z propozycją nawiązania współpracy gospodarczej i kulturalnej, zaczęto snuć wizje zasiedlenia części obszaru tego państwa przez obywateli polskich. 28 kwietnia 1934 roku podpisano umowę, która zobowiązywała rząd liberyjski do wydzierżawienia 50 plantatorom ziemi pod uprawę kauczuku, bawełny kawy, ryżu, kakao. Liga od razu

${ }^{72}$ AAN, KRPM, sygn. 464/265, KRPM do Ministerstwa Przemysłu i Handlu w Warszawie, w sprawie zakazów przywozów, przedstawicielstw oraz przewozu rzeczy do użytku prywatnego w Afryce Północnej, Marsylia, VII.1933 r., k. 5-8; AAN, KRPM, sygn. 464/13, Józef Mańkowski do KRPM w sprawie obrotów handlowych grupy kolonii A.O.F. za pierwsze półrocze 1937 r., Dakar 18.XII.1937 r., k. 40-42; AAN, KRPM, sygn. 464/23, Francuskie Imperium Kolonialne jako rynek odbiorczy dla towarów polskich, Marsylia, 26.XI.1936 r., k. 40-51; AAN, KRPM, sygn. 464/15, KRPM do MSZ, Handel zagraniczny Madagaskaru w 1936 r., Marsylia 30.XI.1937 r., k. 65-72; „Bulletin de l'Agence Générale des Colonies” nr 297 z 12.1933, s. 1470; „Bulletin de l'Agence Générale des Colonies » nr 213 z 03.1926, s. 404.

${ }^{73}$ Liberia zawdzięcza swoją niepodległość, ogłoszoną w 1847 r., Stanom Zjednoczonym. W latach 30 . Liberia zmagała się z różnego rodzaju problemami, w tym handlem niewolnikami. W tej sytuacji do akcji wkroczyła Liga Narodów, chcąc przeciwdziałać temu problemowi i przyjmując plan pomocy ogłoszony 31 października 1932 r. zmierzający do przekształcenia Liberii w protektorat Ligi Narodów. W czerwcu 1933 r. Liberia odrzuciła ten plan. Wywołało to ogromny sprzeciw Wielkiej Brytanii, która rościła pretensje do tego terenu tym bardziej. Liberia graniczyła nie tylko z koloniami francuskimi, ale i brytyjskimi. Liga Narodów, opracowując plan, nie chciała dopuścić do przyznania komukolwiek protektoratu nad Liberią, tym bardziej, że Stany Zjednoczone były mocno zaangażowane gospodarczo w tym regionie, Białas T., Liga Morska i Kolonialna 1930-1939, Gdańsk 1983, s. 210. 
przystąpiła do akcji, inwestując po 20 tys. zł na każdą plantację ${ }^{74}$. Wysłano odpowiednią grupę plantatorów na nowo utworzonej specjalnej linii morskiej z Gdyni. Akcja ta zakończyła się niepowodzeniem dla strony polskiej. Plantatorzy bankrutowali. Udało się założyć jedynie sześć plantacji ${ }^{75}$. Owo przedsięwzięcie od samego początku skazane było na porażkę, gdyż Polska nie dysponowała odpowiednim budżetem na jego rozwinięcie. Z kolei brak precyzyjnych wiadomości o warunkach naturalnych obszarów przeznaczonych pod zasiedlenie - gleba, klimat itp. - przyczynił się do fiaska całej operacji. Jednak decydującym czynnikiem sprawczym okazała się ingerencja Stanów Zjednoczonych, które bacznie przyglądały się poczynaniom strony polskiej. Amerykańscy dyplomaci podsycali wśród władz liberyjskich obawy, że Polska dąży do skolonizowania tego państwa. Nie bez winy w tej kwestii była Liga Morska i Kolonialna, która działała bez porozumienia z rządem polskim, nie popierającym jej pomysłu, a w konsekwencji zmuszonym do tłumaczenia się wobec Liberyjczyków z charakteru całego przedsięwzięcia. Dlatego też władze polskie skierowały swoją prośbę do Ligi Morskiej, aby zaprzestała wszelkich działań na tym terenie ${ }^{76}$. Pomimo zaniechania akcji, na ręce konsula polskiego w Monrowii spływały zapytania o możliwości tworzenia plantacji czy koszta ich utrzymania ${ }^{77}$.

Należy zadać pytanie, jakie znaczenie miał nowy układ dla wymiany handlowej z koloniami z 1937 roku? W stosunkach handlowych z Algierią nie wprowadził żadnych zmian, a podział kontyngentów odbywał się w Paryżu. Polsce zależało, aby Algieria uzyskała własne

${ }^{74}$ Kowalski M.A., Kolonie Rzeczypospolitej Zamorskie zdobycze Polaków - idea i rzeczywistość, Warszawa 2005, s. 329-342.

${ }^{75}$ Kołodziej E., Wychodźstwo..., s. 199.

${ }^{76}$ AAN, MSZ, sygn. 9765, List do Edwina Barcleya o Monrowii, [bd], k. 10-14.

${ }^{77}$ AAN, KRPM, sygn. 464/336, KHRPMnr do KRPM, kartoteka Polaków zamieszkałych w Afryce, Monrowia, 5.VIII.1938 r., k. 179. Według danych statystycznych prowadzonych przez władze konsularne w Liberii w 1938 r. mieszkało 6 polskich plantatorów. 
kwoty kontyngentowe, tak jak miało to miejsce w przypadku Indochin czy Madagaskaru. Większe korzyści z tego układu wyniosła Tunezja. Dzięki stosunkowo niskiej stawce celnej, Polsce udało się rozszerzyć swój eksport, jednakże nie na taką skalę, jakiej oczekiwano, gdyż niektóre towary objęte były ograniczeniami, wynikającymi z unii celnej kolonii z Francją. Dzięki układowi lipcowemu Polska uzyskała stawki minimalne dla eksportu do Madagaskaru i Indochin, choć handel z tymi krajami był w stanie embrionalnym, ze względu na oddalenie geograficzne, brak bezpośredniego okrętowego połączenia oraz związane z tym kwestie finansowe. Natomiast w wymianie z Marokiem, Afryką Zachodnią oraz terytorium mandatowym Syrią i Libanem, towary polskie korzystały z klauzuli największego uprzywilejowania, względnie z parytetu celnego z mocy odnośnych umów międzynarodowych. Polska szukała także możliwości wyeliminowania konkurencji, tak jak to miało miejsce w przypadku naczyń emaliowanych sprowadzanych z Czechosłowacji na rynek Madagaskaru ${ }^{78}$. Naczynia te były stosunkowo tanie, kolorowe, bardzo lekkie i dobre jakościowo. Firmy polskie, by pozyskać ten fragment rynku, musiałyby wysyłać próbki towaru przez przedstawicieli, którzy byli niezbędni w handlowych pertraktacjach, a których Polska nie miała, a powinna mieć, ponieważ kupiec detaliczny - Malgasz jest z natury rzeczy bardzo nieufny, nie kupi towaru zanim go dobrze nie obejrzy ${ }^{79}$. Eksport z Madagaskaru do Polski odbywał się za pośrednictwem domów handlowych Francji, Wielkiej Brytanii i Niemiec. Na całokształt stosunków handlowych Polski z koloniami francuskimi ogromny wpływ miał przepływ towarów drogą morską. Brak bezpośrednich połączeń i uzależnienie Polski od zachodnich państw europejskich w przewozie produktów nie stanowił dogodnych warunków sprzyjających rozwojowi wymiany.

\footnotetext{
${ }^{78}$ Żukowski P.M., op. cit., s. 160.

79 AAN, KHRPTan, sygn. 3, Sprawozdania Zbigniewa Michałowskiego o Możliwości zastapienia towarów czeskich - towarami polskimi w imporcie na Madagaskar, Tananariwa, 20.IV.1939 r., k. 45.
} 
Należy skonstatować, że stosunki gospodarcze pomiędzy Drugą Rzecząpospolitą a Trzecią Republiką nie rozwijały się najlepiej. Francja patrzyła przez pryzmat wzmocnienia własnej gospodarki i to ona dyktowała warunki, na które godziła się Polska, za cenę utrzymania sojuszu politycznego i konwencji wojskowej. Polityka francuska względem Drugiej RP uzależniona była w dużej mierze od sytuacji geopolitycznej. Czy Francja traktowała Polskę jak półkolonię? Zdecydowanie tak, o czym świadczą wszystkie próby wymuszania ustępstw i uzależniania warunków umów politycznych od spraw gospodarczych. Rodzi się kolejne pytanie, a mianowicie: czy Polska mogła temu zaradzić? Odpowiedź jest, niestety, negatywna. Nie miała wystarczających zasobów finansowych, które umożliwiłyby jej kreowanie samodzielnej polityki ekonomicznej. Ponadto nie radziła sobie z wykorzystaniem narzędzi takich jak właściwa reklama ekonomiczna. Nie mogła pozwolić sobie na tworzenie własnych przedstawicielstw ekonomicznych w postaci domów handlowych. Jedynym realnym przedsięwzięciem w tej kwestii było promowanie towarów na targach, które odbywały się w Paryżu, Marsylii, Lille, Lyonie. Ważną rolę w stosunkach gospodarczych odegrały polskie placówki konsularne. Raporty ekonomiczne przez nie sporządzane, mają bogatą treść. Dzięki nim władze polskie miały możliwość analizowania wymiany handlowej Francji z innymi krajami oraz koloniami. Informacje te jednak nie przyczyniły się do zwiększenia obrotów. Po części winę w tej kwestii ponosili polscy i francuscy przedsiębiorcy, którzy nie potrafili nawiązać stałej kooperacji. Strona polska z kolei nie wykorzystała w pełni portu w Gdyni, z możliwością rozwinięcia komunikacji polskiej floty handlowej z portami francuskimi i posiadłościami kolonialnymi. 